\title{
Communications in the Novgorod Region during the Crisis Period of the Time of Troubles
}

\author{
A.A.Selin
}

For citation: Selin A. A. Communications in the Novgorod Region during the Crisis Period of the Time of Troubles. Vestnik of Saint Petersburg University. History, 2018, vol.63, issue 3, pp.748-762. https://doi.org/10.21638/11701/spbu02.2018.305

The expansion of the Muscovite State to Novgorod and Pskov lands in the late fifteenth - early sixteenth century was followed by the spread of the process of state building in the newly incorporated territories. These processes started in Muscovy itself at the same time, in the late fifteenth century. The creation of the communication net provided by the central power played a major role in the processes. The system of state roads appeared in order to provide uninterrupted communication for military and diplomatic aims. New roads with a special system of "yam" distances served mostly to transport troops and escort embassies. The road system organized in Muscovy in the late fifteenth - early sixteenth century directly stemmed from military and diplomatic needs, and was part of shaping the Early Modern state system. It connected Novgorod the Great with the most important fortresses and with the border. During the political crisis of the early seventeenth century, the trunk road system was thoroughly supported by any current authorities. Military events stimulated authorities to increase their control over the roads: a system of outposts was developed at the time. By 1616-1617, however, the mobilization potential of Novgorod government had been exhausted. Some years after the Stolbovo Treaty of 1617, the overland trunk roads came into decline. A reliable connection between Novgorod and Moscow was provided by circular river routes bypassing the devastated lands. Only since early 1620 s, the process of restoring the main trunk roads in Novgorod land had started.

Keywords: Novgorod, Time of Troubles, trunk roads, yam system.

\section{Система коммуникаций Великого Новгорода в кризисный период Смуты}

\section{А.А. Селин}

Для цитирования: Selin A.A. Communications in the Novgorod Region during the Crisis Period of the Time of Troubles // Вестник Санкт-Петербургского университета. История. 2018. Т. 63. Вып. 3. С. 748-762. https://doi.org/10.21638/11701/spbu02.2018.305

Приход Московского государства в Новгородскую и Псковскую землю сопровождался распространением на эти территории тех процессов выстраивания системы государственного управления, которые охватили саму Московию в конце XV - начале XVI в.

Adrian A. Selin - Doctor in History, Professor, National Research University "Higher School of Economics", St. Petersburg Campus, 17, Promyshlennaya str., St. Petersburg, 190000, Russian Federation; aselin@hse.ru

Адриан Александрович Селин - д-р ист. наук, проф., Национальный исследовательский университет «Высшая школа экономики», Санкт-Петербургский филиал, Российская Федерация, 190000, Санкт-Петербург, Промышленная ул., 17, oф. 104; aselin@hse.ru

(C) Санкт-Петербургский государственный университет, 2018 
Важное место в этих процессах занимало и создание центральной властью системы коммуникаций - строительство дорог, предназначенных для бесперебойного исполнения государственных нужд, прежде всего военных и представительских. В это время были сооружены дороги, соединявшие Новгород Великий с крепостями (пригородами), а также ведшие к границам. По новым дорогам, обеспеченным ямской гоньбой, осуществлялась переброска войск и сопровождались посольства. Организация дорожной сети в конце XV - начале XVI в. прямо вырастала из потребностей войны и дипломатии и была частью становления раннемодерной государственной системы в целом. В годы политического кризиса начала XVII в. систему магистральных дорог, необходимую для правильного перемещения воинских сил и посольств, любые власти старались всячески поддерживать. Контроль за дорогами стал важнейшей задачей всех противоборствующих сторон. В это время шло строительство острожков - небольших укреплений, развивавших систему новгородских пригородов. Взятие Новгорода в июле 1611 г. войсками генерала Я. Делагарди всерьез изменило политическую картину Северо-Запада, однако те тенденции в развитии дорожного строительства, которые наметились на первых этапах Смуты, развивались. К 1616-1617 гг. мобилизационные возможности новгородского правительства были исчерпаны. После Столбовского мира 1617 г. в течение нескольких лет сухопутные магистральные дороги находились в упадке и для надежного сообщения Новгорода с центром использовались кружные водные пути, обходившие разоренные земли. Заметно изменился срок, за который гонцы могли достигать столицы. Только с начала 1620-х годов был запущен процесс восстановления основных магистральных дорог в Новгородской земле.

Ключевые слова: Новгород Великий, Смутное время, магистральные дороги, ямская гоньба.

The inclusion of the Novgorod and Pskov lands into the Muscovite State in the late fifteenth - early sixteenth century was followed by the spread of the process of state building in the newly incorporated territories. Those processes actually started in Muscovy at the same time, in the late fifteenth century. The creation of the communication net provided by the central power played a major role in the processes. The system of state roads appeared in order to provide uninterrupted communication for military and diplomatic needs. New roads where special system of " $y \mathrm{am}$ " distances was established served mostly to transport troops and escort embassies.

The road communication system in Muscovy in the late fifteen - seventeenth cc. is a well-studied subject in the historiography. However, most modern-day researchers fail to demonstrate a contemporary perspective. Traditionally, Muscovite "yam station" is believed to have corresponded to a medieval Tartar road tax - "yam". I suppose that searching for the Tartar roots of the Muscovite "yam station" system is only possible through the prism of existence of the centralized communication system, which came into being due to military-diplomatic tasks of the state rather than in response to the demands of local societies. Before Muscovy came to Novgorod and Pskov, the main local roads had led from a big city to local parish and administrative centers - pogosts. In the sources of the seventeenth century, some traits of that system were archaically preserved: distances from Novgorod to each of 350-360 such centers were measured and fixed ${ }^{2}$. Until

${ }^{1}$ Kozlovskii I.P. Pervye pochty i pochtmeistery v Moskovskom gosudarstve. Opyt issledovaniia nekotoryh voprosov iz istorii russkoi kul'tury vo 2-i polovine XVII v. Vol. 1. Warsawa, 1913. P. 20.

2 Podrobnaia rospis' selenii pyatin novgorodskih, vypisannaia iz staryh novgorodskih izgonnyh knig XVII veka s pokazaniem rasstoyanii kazhdogo seleniia ot Novgoroda: Evgenii (Bolhovitinov) // Istoricheskie razgovory o drevnostiah Velikogo Novgoroda. Velikii Novgorod, 2009. P. 112-119. 
the 1480s, there had been no centralized network of roads. Only in the first decades of the Muscovite supremacy, new trunk roads connected Novgorod with all its suburbs (small fortresses) as well as Moscow. So, searching for any Tartar trace in the shaping of the trunk road system in the Russian North West does not lead to anything certain.

Another issue is whether there was any correlation between the Muscovite "yam station" and the European Early Modern system of road organization. All the assumptions in this sphere are based on flimsy foundations. There is no doubt that any European experience was not (or almost not) taken into account in the process of making roads in the Novgorod and Pskov Region in the late fifteenth - early sixteenth centuries (ill. 1). There are no direct sources to claim that some European engineering technologies were used during the construction of those roads. Archaeological excavations could possibly give an answer, especially as far as the borderland is concerned. There is only one research in the archaeology of Early Modern roads: the excavation of the King's Road in Karelia, between Kexholm (Korela) and Kronoborg (Kirjazh) ${ }^{3}$. But this study does not give any explicit answer whether there was any European influence on the Early Modern Russian road making techniques or not.

I suppose that the European experience was not used in the shaping of the trunk road system in Muscovy. The same could be said about the road system in the Great Princedom of Lithuania (however, Muscovite secretaries knew the Lithuanian road system) ${ }^{4}$. It seems that the road system organized in Muscovy in the late fifteenth-early sixteenth century was brought to life by the needs of war and diplomacy, and was a part of building the Early Modern state system, in general.

During the sixteenth century the road system was improved. By the end of the century, a dense network of trunk roads connecting Novgorod with Moscow, Pskov, and all their suburbs had spread all over the Novgorod Land ${ }^{5}$ (fig. 1). A special regional institution, Yam Secretary, governed the Novgorod roads ${ }^{6}$. The system of yam stations was developed. Yams fixed road distances, and each yam was responsible for a certain distance. Each yam was able to hold a fixed number of horses and yam volunteers (elected and delegated by local communities). It was forbidden for yam volunteers to practice the chase along the rivers, they had to use only ground roads. Yams were landowners supplied with villages inhabited by peasants. In the course of the internal and external political cataclysms of the second half of the sixteenth century, the yam system was partly destroyed. It was reestablished in a partly simplified form (the number of yams was reduced, so the distances increased) in 1592. The establishing of yam stations was a responsibility of yam officials (prikazchiki). Road works became a duty of local peasants (a more or less similar system

${ }^{3}$ Bel'skii S. V., Gerasimov D. V., Lipatov A.A., Mikhailova E.R., Murzenkov D.N., Sobolev V.Yu., Fedorov I.A., Shmelev K.V. Korolevskaia doroga mezhdu Keksgol'mom i Kronoborgom: rezul'taty issledovanii istoricheskoi dorogi v Severo-Zapadnom Priladozhe // Materialy polevyh issledovanii MAE RAN. Ess. 13. St. Petersburg, 2013. P. 153-173.

4 Wysłouch S. Posługi komunikacyjne w miastach w.ks. Litewskiego na prawie Magdeburskiem do połowy XVI w. Wilno, 1936.

${ }_{5}$ Golubtsov I.A. Puti soobshcheniia v byvshikh zemliakh Novgoroda Velikogo v XVI-XVII vv. i otrazhenie ikh na karte serediny XVII v. // Voprosy geografii. 1950. Vol. 20. P. 270-300.

${ }^{6}$ Dmitry Liseitcev proposed that Novgorod Jam Secretary was not a person responsible for jam chase but a Court Secretary responsible for food gaps (Russian jama, яма) (Liseitsev D. V. Prikaznaia sistema Moskovskogo gosudarstva v epokhu Smuty. Moscow; Tula, 2009. P. 169). 


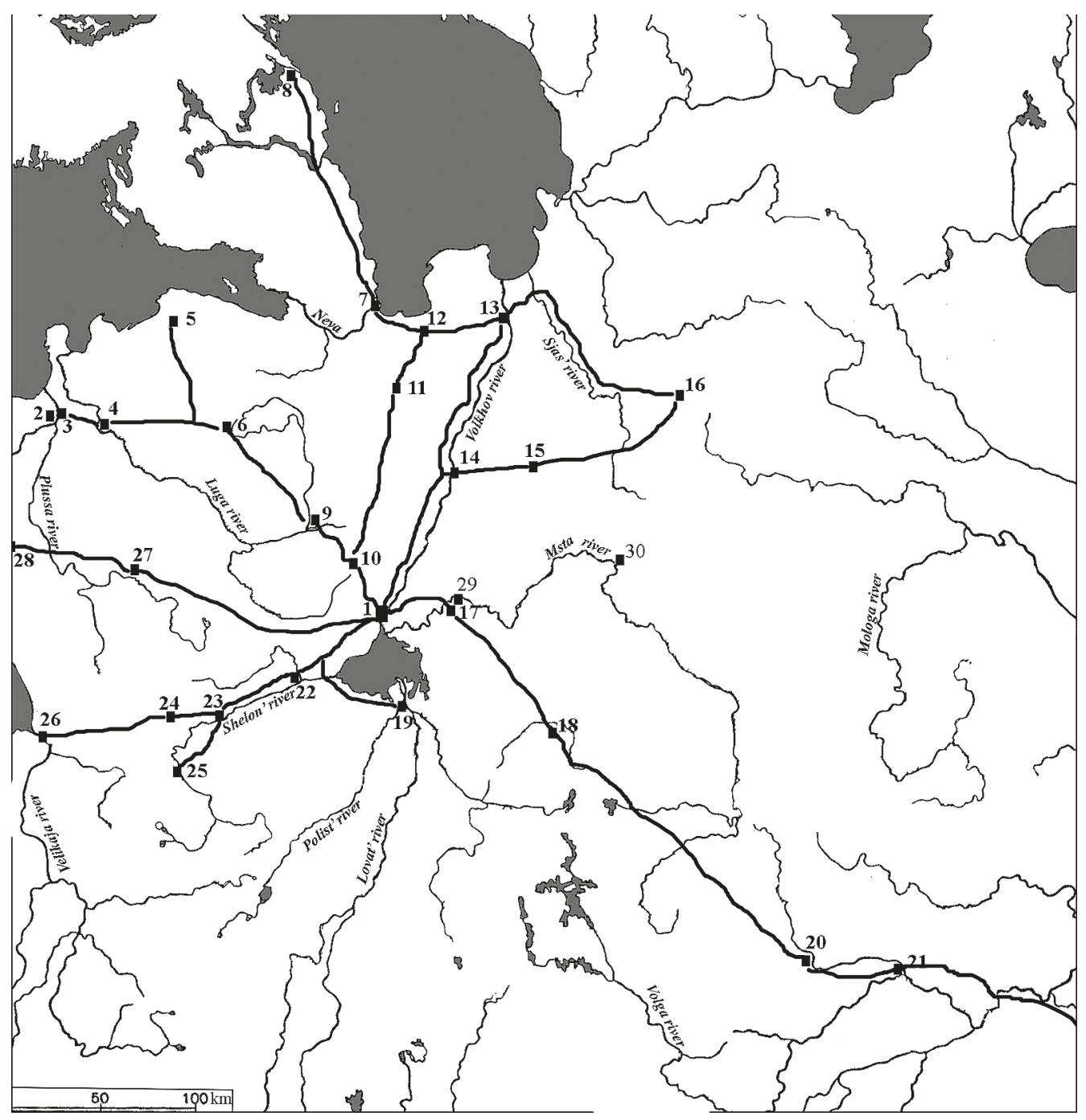

Fig. 1. Roads in the Novgorod Land

1 - Novgorod; 2 - Narva; 3 - Ivangorod; 4 - Jam Fortress; 5 - Koporje; 6 - Zarechje; 7 - Oreshek; 8 - Korela; 9 - Tesovo; 10 - Lussk jam; 11 - Shapki jam; 12 - Nazja jam; 13 - Ladoga; 14 - Gruzino; 15 - Dereva; 16 - Tikhvin; 17 - Bronnitzy; 18 - Jazhelbitzy; 19 - Staraja Russa; 20 - Torzhok; 21 Tver'; 22 - Phaga jam; 23 - Opoki monastery; 24 - Dubrovno jam; 25 - Porkhov; 26 - Pskov; 27 Lyady pogost; 28 - Gdov; 29 - Priluki; 30 - Beloe.

was accepted in the Swedish Livonia in the seventeenth century) ${ }^{7}$. A special incentive to undertake road rebuilding was connected with preparation for the visit of Prince Hans of Holstein to Novgorod and Moscow in 1602. Such system was also kept at the beginning of the Time of Troubles and after the appearance of the Swedish administration in Novgorod in 1611. When the alliance treaty between Swedish General Jacob De la Gardie and

${ }^{7}$ Küng E. Otnosheniia Shvetsii i Rossii v voprosah organizacii pochtovoi sviazi vo vtoroi polovine XVII v. // Smutnoe vremya v Rossii. Konflikt i dialog kul'tur. St. Petersburg, 2012. P. 125-130. 
Novgorod stockholders was signed, the security on the roads was reinforced. Numerous new outposts (ostrozhki) were built along the trunk roads. Oleg Kurbatov supposed that such outpost building was the first serious influence of the West European (Dutch) tactic in Muscovy ${ }^{8}$. During the Time of Troubles, military detachments moved from one outpost to another along those trunk roads.

\section{Moscow Road}

The most important trunk road in the Novgorod Land was a road that connected the city with Moscow. The most vital military events of 1609-1611 happened along its route. Since 1613, when Moscow and Novgorod the Great were involved in military confrontation, the significance of the Moscow Road had lessened.

At its very beginning, the trunk road from Novgorod to Moscow passed through the Khutyn' Monastery9. Then it led to the yam in Bronnitzy. Not once Bronnitzy had been a place where the attempat at the siege of Novgorod was started (in 1610, by De la Gardie in August and by Ivan Saltykov in October; in 1614, by Prince Trubetskoj). During the Time of Troubles, military detachments constantly moved along the road; new fortified outposts were built there: in Bronnitzy, in Viny and in Kolomno. In the autumn of 1616, after Novgorod had lost the eastern part of its district, a great military investigation was initiated along the Moscow road: there was no information about the Moscow side ${ }^{10}$. That was the last military event when ordinary detachments of Swedes and Novgorodians acted together.

After 1617, when the Stolbovo Treaty was signed, the Moscow Road did not immediately become either a safety zone or a reliable communication way. Bridges on the road had been destroyed, and restoration was very slow. In 1620, podyachy Afanasij Muranov received an order to organize construction of the bridges on the Moscow Road with such a description: "There is no ford for livestock on the Nisha River, therefore, Tsar's horses and yam horses are in predicament, in autumn and in spring they are rafted across the river... The raft should be made up of twenty logs with grooves, and on both banks of the Nisha river bridges should be built so that horses with carts will be able to step on rafts and those bridges should be strengthened" ${ }^{11}$. There was no constant and fast communication between Novgorod and Moscow until 1620.

\section{Dubtsy Road}

The Dubtsy Road appeared in the east of the Novgorod Land at the time of Novgorod independence. Alexej Frolov studied its topography and localized its route. During the Time of Troubles, the Dubtsy Road connected Novgorod with its eastern district, the Derevskaja Pyatina. In May 1612, servicemen Semen Korsakov and Drugan Maslenitskij,

\footnotetext{
${ }^{8}$ Kurbatov O. A. Voennaia istoriia russkoi Smuty nachala XVII veka. Moscow, 2014. P. 86-88.

9 Prozorovskii D. I. Novgorod i Pskov po letopisiam s dopolneniem po drugim istochnikam do seredini XVII v. St. Petersburg, 1887. P. 44.

${ }_{10}$ Rossijskii gosudarstvennii arkhiv drevnikh aktov (further - RGADA). F.96. Op.1. R.2. 1616 g. N 7. F. 384-387.

11 Arkhiv Sankt-Peterburgskogo instituta istorii Rossijskoj akademii nauk (further - SPbII). Coll. 276. Op. 1. N 27. F. 405-407.
} 
and podyachy Tretjak Posadnikov went along the Dubtsy Road to the 'Beloozero Frontier' in order to choose the best way for an embassy returning from Novgorod to Yaroslavl'. Korsakov and his associates had to gather food and to supply stations along the Dubtsy Road $^{12}$. In June 1612, serviceman Ivan Bazlov was also sent along the Dubtsy Road to gather food for Swedish soldiers passing to the east and to place it at the Terebyshevo Station. That was the latest mentioning of the Dubtsy Road in the sources. It was not restored after the Time of Troubles.

\section{Belaja Road}

The Belaja Road passed from Novgorod to Bronnitzy, then to the Priluki Yam, then to the Khubtzy and Kolomno Pogosts, and through pogosts on the Belaja River to Borovichi. The road ran along the Msta River and was used mostly in the winter time. In 1612, peasants of the Kostritzy District complained to the Novgorod government that as many as four roads ran through their villages: a waterway along Msta, and three overland ones: the Dubtsy Road, the Belaja Road, and the Tikhvin Road. According to their petition, the roads were the cause of the devastation of the district ${ }^{13}$. In 1612, the Novgorod government tried to equip the Belaja Road and started to gather resources for its repair ${ }^{14}$. The earliest preserved description of the road was done at that time ${ }^{15}$. In August 1612, podyachy Mikhail Kudrjavtsev was sent along that road to meet Abbot Gennadij and Prince Fedor Chernyj-Obolenskij returning to Novgorod from Yaroslavl', together with Yaroslavl' Militia Envoy Prokofij Sekirin ${ }^{16}$.

\section{Ivangorod Road}

The Ivangorod Road was an important artery connecting Novgorod with the Baltic Sea. Most of the Swedish militaries and envoys moved along the Ivangorod Road during the Time of Troubles, especially after King Gustav Adolf came to Narva in 1614. On the plan of the Novgorod siege, 1611, the Ivangorod Road was named Via Coporiam ducens (the Great Koporje Road) ${ }^{17}$ with two monasteries near the city: probably, known as the Bogojavlenskij and Trekhsvjatskij Monasteries on the Vodskaja Road. When Ivangorod was in the hands of rebels (1609-1612), the Ivangorod Road served as a way from Novgorod to the Koporje Fortress ${ }^{18}$.

In 1611-1617, the road was continuously used. In June 1612, food warehouses at the Kusoni, Tesovo, and Zarechje Stations were established in order to supply military detachments sent to the Baltic ${ }^{19}$. In summer 1613, a large number of horse-owning and horseless peasants were taken from villages to the road works on the Ivangorod Road; they were

\footnotetext{
12 Svenska Riksarkiv. Ockupationsarkivet från Novgorod (further - RA, NOA). Serie 2:354. F. 33-34.

${ }^{13}$ Ibid. Serie 2:73. F.72.

14 Ibid. Serie 2:355. F. 3-5.

15 Ibid. F. 41.

16 Ibid. Serie 2:356. F. 69-70.

17 Kovalenko G. M. Shvetsia i Rossia v XVII v.: iz istorii politicheskih i kul'turnyh sviazei // Rapportserie utg. Av Forskningarkivet vid Umeå Universitet. Scriptum N 40. 1995. P. 28.

18 Dopolneniia k Aktam istoricheskim, izdannym imperatorskoi Arheograficheskoi komissiei. Vol. 2. St. Petersburg, 1846. P. 41.

19 RA, NOA. Serie 2:354. F. 51-52.
} 
from the distant Porkhov, and Ustreka Districts ${ }^{20}$. According to some petitions, workers had rebuilt "about 201 sazhens of old bridges behind the Tesovo Station with small spruce, birch, and aspen logs" 21 . The road was under strict control of Swedish militaries. Well-fortified outposts in Tesovo, and Zarechje were built. Well preserved acts on the Ivangorod Road show that the system of road organization shaped in the late sixteenth century had survived in the Time of Troubles. Thus, in 1612/13, bread supply for the yam volunteers of the Tesovo Yam was taken from the Novgorod Court Office ${ }^{22}$. In spite of the growing political crisis, the Novgorod government continuously attempted to organize a direct communication, at least, along the main roads connecting the most important outposts and fortresses (the Ladoga and Ivangorod Roads). The last road repair was undertaken in the summer of 1613, when podyachies Grigorij Sobakin and Maksim Vasiljev were sent to the Somro District in order to collect workers for bridge repair ${ }^{23}$.

In 1618, a Border agreement after the Stolbovo Treaty was signed on the Ivangorod Road, in the site of Osinovaja Gorka, where the road crossed the new border ${ }^{24}$. Since then the character of the road had changed: it ran not from Novgorod to the Baltic Sea, but from Muscovy to the Swedish Kingdom. If its Swedish part had been more or less in order for a century, the Muscovy part had been slowly deteriorating. In the seventeenth century, another name was used for it - the Tesovo Road, after the most important point on its route ${ }^{25}$.

\section{Ladoga Road}

The road from Novgorod to Ladoga ran along the left bank of the Volkhov River. In 1610-1618, the traffic between Novgorod and Ladoga was too intensive. Ladoga and the surrounding territory (Porogi District, Gostinopolje Monastery) repeatedly became the area of military events. The yam in Ladoga, as an important traffic point, was under special scrutiny of the Novgorod government in 1612, when an envoy to Sweden headed by Archimandrite Nikandr was being chosen. At the time the abbot of the Tikhvin monastery Josef complained to Novgorod: "Podyachy Vasilij Ushakov has forcibly taken 100 drays with sleighs, clamps and conductors only from Tikhvin townsmen excluding other pyatina inhabitants"26.

After the departure of Swedes from the Novgorod and Ladoga Districts in 1617, the new authorities restored the yam system. But the overland road from Novgorod to Ladoga had been in a state of repair for a long time. In 1619, an ambassador Prince Fedor Boryatinskij and his associates wrote to Moscow that they had to stay in Ladoga "due to the mud season" waiting for the winter way so that they would have a chance to go out of Ladoga to Moscow "in search of better places to pass through" 27 . When in 1619 Ladoga governors had to send a "Lithuanian traitor" Voin Bedrinskij to Moscow, they used the

\footnotetext{
20 Ibid. Serie 1:34. F. 259-261.

21 Ibid. Serie 2:50. F. 48r.

22 Ibid. Serie 1:34. F. 63-65.

23 Ibid. Serie 1:34. F. 481.

24 Polnoe sobranie zakonov Rossiiskoi imperii. Collection 1. Vol. 1. St. Petersburg, 1838. P.203.

25 Russko-shvedskie ekonomicheskie sviazi. Moscow; St. Petersburg, 1960. N 189. P.309-310.

26 RA, NOA. Serie 2:74. F. 14.

27 SPbII. Coll. 276. Op. 1. N 27. F. 537-538.
} 
way to the east (from Ladoga to the Svir' River, then to Vytegra, and Vologda) and not the traditional roads to Novgorod and Tver'28. The Ladoga yam was restored only in $1622^{29}$.

\section{Oreshek Road}

The road from Novgorod to Oreshek along the Neva River route (that continued then northwards under the name of the Korela Road) was a part of the road network in the northwest of Novgorod lands. It forked from the the Ivangorod Road at the Lussk Yam, and then turned directly to the north. The Oreshek Road passed through marshy and scarcely populated areas. That circumstance led to certain instability in its exploitation. When the state experienced a shortage of resources, the road was abandoned.

In the early seventeenth century, however, the Oreshek Road was restored. In 1612, Swedish troops moved along it from Novgorod to the Volzhino Yam, and then to Oreshek $^{30}$. After 1617, similarly to the Ivangorod Road, the Oreshek Road was also divided into two parts: one went out of use (in Muscovy) and the second was abandoned (in the Swedish Kingdom).

\section{Road from Ladoga to Oreshek}

The road connecting Ladoga and Oreshek was also one of the key routes in the political events of the early seventeenth century. It ran from the center of the Ladoga Town along small rivers the Ladozhka and the Kobona, by the St. Feodor Pogost in Peski to the village of Gorodische on the Lavuja River. About 1617, the Lavuja outpost was built in that place. From that outpost the road ran to the St. George Pogost in Lop', and then to the Nazja Yam, where it was connected with the Oreshek Road.

Although the data about the history of this road during the Time of Troubles is scarce, there is no doubt that it was in use, for example, when Klaes Slang marched from Ladoga to Oreshek in the winter of 1611/12. The sources mentioned the distance of the road 70 verstas $^{31}$. There is a description of the road given in 1670s by Erick Palmquist: "There were once timber causeways along the route, at the time of Count Jakob De la Gardie, but owing to neglect, the road is now in a state of complete disrepair. In summer, therefore, the going is very difficult, on account of many desolate forests and the boggy ground" 32 . The sources used by Palmquist are, unfortunately, unknown.

\section{Pskov Road}

The road from Pskov to Novgorod seems to have been one of the most ancient in the area. It started in Novgorod at the Alexey Yam settlement ${ }^{33}$. The part of the road closest to

${ }^{28}$ Ibid. Coll. 153. Op. 1. N. 52.2.

${ }^{29}$ Ibid. F. 109. Op. 1. N. 82.

30 RA, NOA. Serie 2:354. F. 35-37.

31 Golubtsov I. A. Puti soobshcheniia... P. 294-300.

32 Zametki o Rossii, sdelannye Erikom Pal'mkvistom v 1674 godu // Några Observationer angående Ryssland, sammanfattade av Erik Palmquist år 1674 / eds U. Birgegård, E. Löfstrand, L. Nordquist. Moscow, 2012. P. 123.

${ }^{33}$ Dela Tainogo prikaza. Vol.2. St. Petersburg, 1908. P. 456-492. 
Novgorod passed through marshy area. Since the late sixteenth century, there had been an alternative way from Pskov to Moscow without turning to Novgorod: to the Yuriev Monastery, then through Ilmen' Lake directly to Bronnitzy, and to the Great Moscow Road ${ }^{34}$. During the Time of Troubles, the Pskov Road was a trunk road on the Novgorod-Pskov frontier ${ }^{35}$. The Verjazha Yam on the road had important strategic value. It was the point where a fork was: the way to Staraja Russa ran to the left, the way to Pskov ran to the right. In the winter of $1611 / 12$, the station in Verjazha became a place for a winter camp of the Swedish detachment. In the late December 1611, a certain Novgorod officer Timofej Tyrtov reached this detachment and immediately sent his food-takers to the surrounding villages ${ }^{36}$. On December 25, he wrote to the Novgorod government that his gatherers Ivan Zabelin and Vasilij Sytin had not sent any food for Swedes yet, and that there was enough food for soldiers for a week only. Distributing money instead of food fueled resentment.

During 1615 and 1616, the moving of Swedish and Novgorod troops along the Pskov Road was very intensive because of the King Gustav Adolf's dream to conquer Pskov.

After the Time of Troubles, the Pskov Road was temporarily out of use. In 1624, the Pskov yam volunteers remembered: "when Novgorod, Porkhov, Ivangorod, and Gdov were taken by Germans (Swedes. - A. S.), there was no direct road from Pskov to Moscow; carriages with envoys and couriers passed from Pskov to Toropets, then to Moscow". In 1624, all yam stations between Novgorod and Pskov, except one in Zagorje, were closed ${ }^{37}$.

\section{Tikhvin Road}

The road from Novgorod to the Great Tikhvin Monastery had existed, at least, since the sixteenth century ${ }^{38}$. The trunk road was probably organized along the old way from Novgorod to the Obonezhje Region, on the basis of a system of local roads connecting pogosts with each other. Having been restored in the early seventeenth century, the Tikhvin Road turned away from the Ladoga Road at the Pnevo Yam, then led to the Pshevzha Yam, and then later eastwards (the Kremenitzy Pogost, and the Sjas' River) ${ }^{39}$. Yam volunteers who served in Pnevo in order to facilitate their efforts used lighter means of transport and passed half of the way in boats (by the rivers Volkhov and Oskuja) ${ }^{40}$. There is a lack of data about any yam in Tikhvin. In any case, the road was in use during the siege of the Tikhvin Monastery by Swedish-Novgorod troops in 1613.

\section{Road between Tikhvin and Ladoga}

Traffic from Tikhvin to Ladoga was provided along the Sjas' River, then near St. Nickolas Pogost on Sjas' the road turned westwards and ran straight to St. Basil Monastery on the Volkhov, just opposite the Ladoga stone fortress. Half of the road near Tikhvin was

${ }^{34}$ Lihachev N.P. Delo o priezde Antoniia Possevina // Letopis' zanyatii arheograficheskoi komissii. 1888-1894. Ess. 11. St. Petersburg, 1903. Part 3. P. 64.

35 RA, NOA. Serie 2:354. F.35-37.

36 Ibid. Serie 2:362. F. 13-15.

37 Akty, sobrannye Arheograficheskoi ehkspeditsiei v bibliotekakh i arhivakh Rossiiskoi imperii (further - AAE). Vol.3. St. Petersburg, 1836. N. 154. P. 224-226.

38 Golubtsov I. A. Puti soobshcheniia... P. 296.

39 SPbII. Coll. 276. Op. 1. N. 27. F. 136, 133

40 Ibid. F. 128-129. 
vividly described in June 1616 by captain of musketeers Semen Dunilov who was in search of a place for the treaty negotiations. In the process of the search, the village of Stolbovo on the Sjas' River was proposed as such a place ${ }^{41}$.

There was an alternative way from Ladoga to Tikhvin via the Zelentzy Monastery, and the archbishop's Zabolotje District, then along the river of Volkhov northwards to Ladoga. That way was used by Tikhvin musketeers appointed to spy in Ladoga area in June $1616^{42}$ (fig. 2).

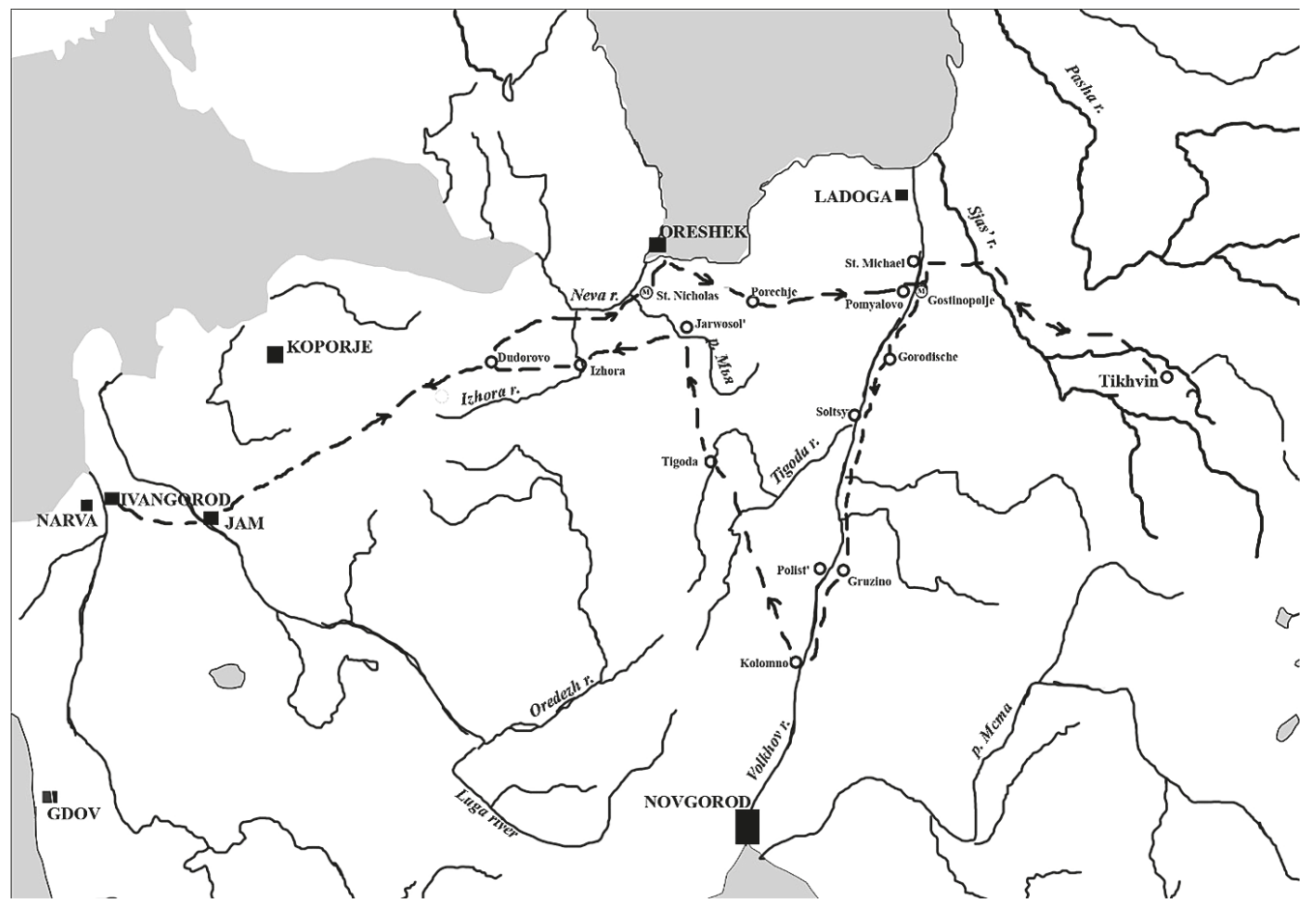

Fig. 2. Way of Tikhvin musketeers from Tikhvin to Ivangorod and back. July 15 - August 12, 1616

\section{Road from Tihkvin to Moscow}

During the negotiations in Ladoga, and then in Stolbovo in 1616-1617, a communication between Tikhvin (where main headquarters of the Muscovite Embassy was situated) and Moscow was carried out very intensively. The communication was provided by two ways.

The first one ran from Tikhvin to the Kolbyagi Pogost, then to the Ustreka Districts, and then to Borovichi, where the road joined the Great Moscow Road. There were few mentions about that road; however, when in 1613 Prince Prozorowskij and Leontij

${ }^{41}$ Selin A.A. Smuta na Severo-Zapade v nachale XVII veka. Ocherki iz zhizni novgorodskogo obshchestva. St. Petersburg, 2017. P. 629-633.

${ }^{42}$ RGADA. F. 96. Op. 1. R. 2. 1616 g. N.7. F. 270-273. 
Plescheev went to Tikhvin, they used that route ${ }^{43}$. In 1624, the road was mentioned in the investigations concerning the great fire that destroyed the Senno Station in the Kolbyagi Pogost ${ }^{44}$.

The alternative way was a road from Tikhvin directly eastwards to Ustjuzhna. All the reports by Tikhvin governors, and, since the summer of 1616, all the reports by Prince Mezetskij's Embassy went to Moscow via that way, not through the dangerous Bezhetskaja Pyatina. Yam stations on that road had been mentioned since the very beginning of the Time of Troubles ${ }^{45}$.

When in 1611-1617 military troops intensively moved all over the north-west of Muscovy, it was the Novgorod government who took care of the trunk roads. Until 1613, its efforts wer e more or less successful. But since, at least, 1615, the main movements had been provided along the rivers, not along the cobbled roads. When Swedish envoys S. Appelmann and H. Brakil came to Peski (between Staraja Russa and Ostashkov), where they met the envoys from Moscow, Swedes had to explain their delay: "there was a storm on Ilmen' Lake and passing the rapids was very difficult" 46.

The only preserved picture of the early seventeenth century trunk road also dates back to the Time of Troubles. The carving by Antonis Goeteeris (1616) depicts a section of the Ivangorod Road, somewhere between Vruda and Tesovo Yam stations. The road is made of rows of logs placed perpendicularly the main direction ${ }^{47}$.

Up to 1616, the Novgorod Land covered a vast space where quite different people moved in various directions. The movement increased during the last months before the Stolbovo Treaty was signed. The guards were only at the outposts, and travelers invented all kinds of routes.

In July 1616, two musketeers from Pskov came to Tikhvin. They had been formerly imprisoned by Swedes and kept at the estates of one Narva stockholder, some seven verstas from Narva. On June 21, they ran away from the estate and succeeded in reaching Ivangorod. Then, on June 29, they both headed for the Yam Fortress, then to Slovenka on the Izhora River. After that, their way was to the Lopp' Pogost, and then to the Volkhov River. At the distance of three verstas from Ladoga (where large Swedish garrison was situated) the musketeers crossed the Volkhov River, and successfully reached Sjas' outposts with Muscovite Cossacks ${ }^{48}$.

At the same time, on July 15, 1616, two Tikhvin musketeers Petr Maksimov and Ivan Vasiljev were sent to spy in the Ivangorod area. They started their way from Tikvin to St. Michael Pogost on Volkhov, then to the Kolomno Pogost on Volkhov (up the river). At this point Maksimov and Vasiljev turned westwards (Yarwosol', Izhora, and Dudorovo Pogosts). On July 27 they reached Ivangorod, spent a night there at local Fedotko, and in the morning started their way back. In two days they reached Yarwosol' Pogost, and turned northwards to Oreshek. On August 2, a local priest Jury Moiseev brought the musketeers

${ }^{43}$ Kurbatov O. A. Tihvinskoe osadnoe sidenie 1613 goda. Moscow, 2006.

44 AAE. Vol. 3. St. Petersburg, 1836. N. 154. P.220-221.

45 Smutnoe vremia Moskovskogo gosudarstva. Iss. 2. Akty vremeni tsaria Vasiliya Shuiskogo (1606 g. 19 maia - 17 iulia 1610 g.) / ed. by A. M. Gnevushev. M., 1915. N 4. P. 64.

46 RGADA. F. 96. Op. 1. R. 2. 1615 g. N.3. F. 107-109.

47 Goeteeris Anthonis. Journael der legatie ghedaen inde jaren 1615 ende 1616. The Hague, 1619, fig. $28 / 29$.

48 RGADA. F.96. Op. 1. R.2. 1616 g. N 8. F.24-28. 
to his native Oreshek. In the same night, the spies left Oreshek for St. Nicholas Monastery (four verstas), where they spent the night. They found their way back from St. Nicholas Monastery to Pomyalovo on Volkhov, and then to Gostinopolje, where they crossed the Volkhov River, and successfully returned to Tikhvin ${ }^{49}$.

When Koporje, Ivangorod, the Yam Fortress, and Oreshek became a part of the Swedish Kingdom - Ingermanland, the road system on that territory was developed very intensively. The Ivangorod Road received several branches and lost its unique position for the territory. In 1617, a road from Ivangorod to Koporje was in use, and there was a special Koporje Yam near the fortress ${ }^{50}$.

\section{Travel Speed}

The issue of travel speed during the Time of Troubles is complicated, indeed. Before the period of 1596 and 1598, a special courier could cover the distance between Novgorod and Moscow in six or seven days:

\section{Travel speed (Novgrord - Moscow) in late $16^{\text {th }}$ century $y^{51}$}

Cossack Captain Ivan Ostafjev s. Ozhogin, Novgorod, October, 8 - Moscow, October, 12 (1596).

Nikon Fedorov s. Buturlin, Novgorod, December, 18 - Moscow, December, 22 (1598).

G. Zamyatin noted that in 1612-1613, the reports reached Novgorod from Moscow (and vice versa) in three-five weeks ${ }^{52}$, whereas in 1611 - in eight-nine days ${ }^{53}$. After the Stolbovo Treaty was signed, the same distance could be covered in about two weeks:

\section{Travel speed (Novgorod - Moscow) in 1617-1618}

Podyachy Gavrilo Kuvshinov, Novgorod, June, 8 - Moscow June, 17 (1617).

Ivan Stepanov s. Tyrkov, Ladoga, September, 23 - Moscow, October, 7 (1617).

Zakharij Dolgovo-Saburov, Budkovo Pogost, February, - Moscow, February, 19 (1618).

The champion in going between Muscovite judges on the border and the Ambassador Chancellery in Moscow was Vasilij Filosofov. On October 23, 1617, he set off for Moscow from the Lavuja Camp with the judges' charter. On November 15, he was in the Chancellery. Then, he received new credentials in the Chancellery and departed from Moscow in order to find the border judges somewhere. He found them on the Luga River, at the Storonje Camp, on January 11, $1618^{55}$, but a week before, on January 4, Judge Zherebtsov sent Musketeer Officer Maksim Sudoplatov with a new request for credentials. Sudoplatov reached Moscow only on January $27^{56}$, and returned to the next judges' camp on February $19^{57}$.

49 Ibid. F. 520, 519, 521.

${ }^{50}$ RA, NOA. Baltiska fogderäkenskaper. F. 415. N. 13.

${ }^{51}$ RGADA. F. 96. Op. 1. R. 2. 1596 g. N 4. F. 1; F. 96. Op. 1. R. 2. 1598 g. N. 1. Part 1. F. 61.

52 Zamyatin G. A. Rossia i Shvetsia v nachale XVII veka. Ocherki politicheskoi i voennoi istorii. St. Petersburg, 2008. P. 137.

53 Ibid. P. 213.

${ }^{54}$ RGADA. F. 96. Op. 1. R. 2. 1617 g. N 9. F. 123-124; F. 96. Op. 1. R.2. 1617 g. N 9. F. 149-150; F. 96. Op. 1. R.2. 1617 g. N 9. F.291-293.

55 Ibid. F. 96. Op. 1. R. 2. 1617 g. N 9. F. 294-312, 314, 318-320, 317, 315, 321-334, 336.

56 Ibid. F. 239-249.

57 Ibid. F. 294-312, 314, 318-320, 317, 315, 321-334, 336. 
It was very difficult, wet and uncomfortable to travel at the time. Harsh conditions affected not only people, but also documents. Zakharij Dolgovo-Saburov was sent to Moscow with important charters. He went via Ustjuzhna. While he was on the way in autumn both charters "fell from the carriage to the river, became wet and black". He returned the documents to the judges who sent them to Novgorod to be cleaned ${ }^{58}$.

Filosofov, Sudoplatov, and Dolgovo-Saburov used a winter way. The way in spring was much harder. About March 13, 1618, Ivan Alekseev s. Suslov was sent from Novgorod to the Ambassador Chancellery with a report. He reached Moscow on April $3^{59}$. Ivan Bolshoj Gerasimov s. Ushakov was sent with the same task on March 18, and he reached the Chancellery on April $7^{60}$.

But there were cases, when the distance was covered in a week. Mikhail Ivanov s. Arcybashev started from Novgorod on November $1,1618^{61}$, and on November 8, he was sent back to Novgorod from the Chancellery. At the same time, the way from Pskov to Moscow took about one month ${ }^{62}$.

Travel speed (Pskov - Moscow), 1618-161963

Dementii Mokeev, Pskov, December 18 - Moscow, January 10 (1618 and 1619).

Fedor Dmitriev s. Zelenin, Pskov, November, 30 - Moscow, December, 29 (1618).

\section{Looting on the Roads}

During the Time of Troubles roads were extremely dangerous space. In the autumn of 1613, one of such hazardous areas appeared in the Volkhov River valley, where the Ladoga Road was running. The outpost in Vodosi, halfway between Ladoga and Novgorod, could not provide safety along the whole route. Cossacks from Tikhvin intercepted some letters by Swedish militaries to their families. Ekaterina, the wife of Colonel Hans Rekinberger, wrote (from Ladoga) to her husband (in Novgorod) warning him to be careful while coming to her, and to try to find another way, not by the road along the Volkhov River ${ }^{64}$.Two years later, the safety on this road did not become better. In November 1615, two peasants from the area were interviewed in Tikhvin. They told that Novgorod Governor had sent them to Ladoga with some charters. The Governor told them "not to go by the trunk road, but look for some lanes in the woods in the area". The governor ordered those peasants (and not a Swede) to carry the charter being beware of the "Russian robbers" ${ }^{\text {". However, }}$ those peasants went to the Muscovite Embassy in Tikhvin, not to Swedish authorities in Ladoga.

The merchants with goods, who tried to carry their commodities along the Ivangorod Road, were also often robbed. In 1614, there was an investigation in the Novgorod Court Chancellery. Two merchants, Fedor and Danilo, carried their goods to Narva. They blamed a certain local, Yakush. According to the merchants' testimony, Yakush, accom-

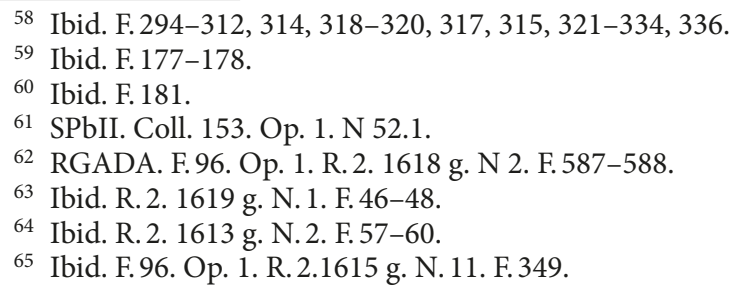


panied by his nephews and associates, robbed them in Zarechje and in the Ruskovichi Village, and took their goods worth 15 Roubles. Earlier that Yakush was a carrier on the Ivangorod Road and immediately an elected elder of the Vruda Pogost. His witnesses, local peasants and carriers, testified that Yakush did not even touch the merchants ${ }^{66}$.

On July 19, 1616, Kuzemka Jakovlev, a servant from the Khutyn Monastery, was secretly sent from Novgorod to Tikhvin by Archimandrite Cyprian. He also was entrusted with some monastery coffers: different monastic vestments, two books, and a horse. On his way to Tikhvin, in the Kashira Village, some 80 verstas from Novgorod, 16 musketeers deserted from Tikhvin attacked him. They robbed him of everything, including the archimandrite's charter, and he could hardly reach Tikhvin ${ }^{67}$.

Not only couriers but also envoys were mugged and robbed. I have already mentioned a looted cortege of appointed Novgorod Governor Prince Khovanskij on his way to Novgorod. Envoy Prince Fedor Boryatinskij was ordered to go from Sweden to Moscow "through those fortresses that are better and where there is no fear of the Lithuanians"68. That was not a simple precaution. Up to the end of November 1618, Prince Boryatinskij waited in Ladoga for the end of mud season, and started his way to Moscow via Tikhvin. Two days after, in Tikhvin, Prince Boryatinskij received a report that "Lithuanians had come to Beloozero and plied near Ustjuzhna". After receiving such information, Prince Boryatinskij returned to Novgorod ${ }^{69}$. It took him nine days. The area between Tikhvin and Ustjuzhna mostly remained dangerous. Even in summer 1619, a certain Swedish courier met a Lithuanian band there, near Ustjuzhna, and barely run away from them, came to Ladoga and stayed there before Lithuanians passed this fortress by ${ }^{70}$. He could only return there safely return there only in the early 1620s.

\section{Results}

The system of trunk roads in the Novgorod Land was one of the most serious innovations provided by the Muscovite state in the northwestern landscape. During the political crisis of the early seventeenth century, all authorities went to any length to support the road system, necessary for military and diplomatic needs. Up to 1616-1617, however, the mobilization potential of the Novgorod government had been exhausted. Some years after the Stolbovo Treaty of 1617, the overland trunk roads came into decline. A reliable connection between Novgorod and Moscow was provided by circular river ways bypassing the devastated lands. Only since the early 1620s, the process of restoring the main trunk roads in Novgorod land had been started.

\section{References}

Bel'skii S. V., Gerasimov D. V., Lipatov A.A., Mikhailova E.R., Murzenkov D. N., Sobolev V.Yu., Fedorov I. A., Shmelev K. V. Korolevskaia doroga mezhdu Keksgol'mom i Kronoborgom: rezul'taty issledovanii istoricheskoi dorogi v Severo-Zapadnom Priladozhe. Materialy polevykh issledovanii MAE RAN.

\footnotetext{
${ }^{66}$ RA, NOA. Serie 2:122. F. 22-24.

67 RGADA. F. 96. Op. 1. R. 2.1616 g. N. 8. F. 325-331.

68 Ibid. F.96. Op. 1. R. 2. 1618 g. N 1. F. 204.

${ }^{69}$ Ibid. F. 238.

${ }^{70}$ Ibid. F. 96. O. 1. R.2. 1620 g. N 2. F. 69-104.
} 
Ess. 13. St. Petersburg, Museum of Anthropology and Ethnography Publ., 2013, pp.153-173. (In Russian)

Golubtsov I. A. Puti soobshcheniia v byvshih zemliakh Novgoroda Velikogo v XVI-XVII vv. i otrazhenie ikh na karte seredini XVII v. Voprosy geografii, 1950, vol.20, pp. 270-300. (In Russian)

Kovalenko G. M. Shvetsia i Rossia v XVII v.: iz istorii politicheskikh i kul'turnykh sviazei. Rapportserie utg. Av Forskningarkivet vid Umeå Universitet, 1995, scriptum N 40, 48 p. (In Russian)

Kozlovskii I. P. Pervye pochty i pochtmeistery v Moskovskom gosudarstve. Opyt issledovaniia nekotoryh voprosov iz istorii russkoi kul'tury vo 2-i polovine XVII v. Vol. 1. Warsaw, Tipografija Varshavskogo Uchebnogo Okruga Publ., 1913, 552 p. (In Russian)

Küng E. Otnosheniia Shvetsii i Rossii v voprosakh organizatsii pochtovoi sviazi vo vtoroi polovine XVII v. Smutnoe vremia v Rossii. Konflikt i dialog kul'tur. St. Petersburg. St. Petersburg State University Press, 2012, pp. 125-130 (In Russian)

Kurbatov O. A. Tihvinskoe osadnoe sidenie 1613 goda. Moscow, Zeichhaus Publ., 2006, 48 p. (In Russian)

Kurbatov O. A. Voennaia istoriia russkoi Smuty nachala XVII veka. Moscow, Quadriga Publ., 2014, 238 p. (In Russian)

Lihachev N. P. Delo o priezde Antoniia Possevina Letopis' zanyatii arheograficheskoi komissii. 1888-1894. Ess. 11. St. Petersburg, Typografija Balasheva i Kº , 1903, part 3, pp.3-281 (In Russian)

Liseitsev D. V. Prikaznaia sistema Moskovskogo gosudarstva v epokhu Smuty. Moscow; Tula, "Grif i K” Publ., 2009, 792 p. (In Russian)

Prozorovskii D. I. Novgorod i Pskov po letopisiam s dopolneniem po drugim istochnikam do serediny XVII $v$. St. Petersburg, F. Eleonskii i K ${ }^{\circ}, 1887,177$ p. (In Russian)

Selin A. A. Smuta na Severo-Zapade v nachale XVII veka. Ocherki iz zhizni novgorodskogo obshchestva. St. Petersburg, BLITZ Publ., 2017, 719 p. (In Russian)

Wysłouch S. Posługi komunikacyjne w miastach w.ks. Litewskiego na prawie Magdeburskiem do połowy XVI $w$. Wilno, Nakladem Institutu naukowo-badawczego Europy Wschodniej z zasilku Funduszu kultury narodowej Publ., 1936, 215 p.

Zamyatin G. A. Rossia i Shvetsia v nachale XVII veka. Ocherki politicheskoi i voennoi istorii. St. Petersburg, "Evropeiskii Dom" Publ., 2008, 502 p. (In Russian)

Received: 30.01.2018

Accepted: 31.05.2018 